\title{
A 3-YEAR FOLLOW-UP OF A BRAZILIAN AIDS PATIENT WITH PROTRACTED DIARRHEA CAUSED BY Enterocytozoon bieneusi
}

\author{
Patrícia BRASIL (1), Daurita D. DE PAIVA (1), Dirce B. DE LIMA (1), Edson Jurado DA SILVA (3), José Mauro PERALTA (2), Alexandre J. DA SILVA (2), \\ Fernando C. SODRÉ (1), Érika Veríssimo VILLELA (1) \& Hércules MOURA (1)
}

\begin{abstract}
SUMMARY
Enterocytozoon bieneusi is the most prevalent microsporidian parasite that causes gastrointestinal infection in persons with AIDS. Microsporidia are increasingly recognized as important opportunistic pathogens all over the world but in Brazil only few cases have been reported due either to the non awareness of the clinical presentation of the disease or to difficulties in the laboratory diagnosis. We report a 3-year follow-up of a Brazilian HIV-positive patient in whom microsporidial spores were detected in stools and were identified as E. bieneusi using electron microscopy and PCR. The patient presented with chronic diarrhea, CD4 T-lymphocytes count below $100 / \mathrm{mm} 3$ and microsporidial spores were consistently detected in stools. Albendazole was given to the patient in several occasions with transient relief of the diarrhea, which reappeared as soon as the drug was discontinued. Nevertheless, a diarrhea-free period with weight gain up to $18 \mathrm{Kg}$ occurred when a combination of nucleoside and protease inhibitors was initiated as part of the antiviral treatment.
\end{abstract}

KEYWORDS: Microsporidia; AIDS; Diarrhea; Brazil

\section{INTRODUCTION}

Microsporidia are intracellular, spore-forming protozoa that infect principally insects, fish, laboratory rodents and humans, specially the immunocompromised. Human intestinal microsporidiosis is primarily caused by two different genera of microsporidia, namely Enterocytozoon bieneusi and Encephalitozoon intestinalis (formerly called Septata intestinalis) ${ }^{13}$. Since the first report of intestinal microsporidial infection in a patient with acquired immunodeficiency syndrome (AIDS) in $1985^{9}$ the species E. bieneusi has gained increasing attention as an important cause of chronic diarrhea in AIDS patients with less than $50-100 / \mathrm{mm} 3$ CD4 T-lymphocytes ${ }^{25}$. There is no established therapy for $E$. bieneusi infection although reports of clinical improvement with metronidazole, albendazole, furazolidone, thalidomide, azithromycin or atovaquone exist ${ }^{1,10,21}$. On the other hand, $E$. intestinalis, that causes both a gastrointestinal disease, and a disseminated disease involving the biliary tract, kidneys, liver, tongue, lungs and eyes ${ }^{3}$, could be eradicated after albendazole therapy ${ }^{10,14,26}$.

Until 1990, both light and electron microscopic examinations of small intestine biopsy sections were required to diagnose the species of enteric microsporidia. The availability of recently developed morphologic ${ }^{8,18,22}$ and non-morphologic ${ }^{7,12}$ diagnostic techniques for the detection of microsporidial spores in stool samples allows the diagnosis of the particular species in increasing number of cases around the world 1,3,8,11,15,19,20,21,23,25. However, if specific molecular probes for the polymerase chain reaction (PCR) are not available, transmission electron microscopy (TEM) of infected tissues may be required for definitive species identification ${ }^{5}$, which is important for initiating therapeutic strategies ${ }^{6}$.

To date, only a few cases of intestinal microsporidiosis have been reported in BRAZIL ${ }^{2}$. However, in none of the studies the causative species has been determined. We describe in this report a Brazilian patient with a 3-year history of protracted chronic diarrhea who was identified to be infected with $E$. bieneusi as the sole pathogen based on TEM and PCR techniques and also showed improvement of gastrointestinal symptoms after treatment with a combination of nucleoside and protease inhibitors.

\section{CASE REPORT}

A 37-year-old homosexual male weighting $60 \mathrm{~kg}$ was first diagnosed with human immunodeficiency virus type 1 (HIV) infection in 1991. He was evaluated in May 1994 for chronic diarrhea (15 episodes of watery stools per day) nausea and vomiting, anorexia, intermittent right upper quadrant abdominal pain and a

(1) Departamento de Parasitologia e Patologia; Serviço de Doenças Infecciosas e Parasitárias, Departamento de Medicina Interna, Faculdade de Ciências Médicas (FCM), Universidade do Estado do Rio de Janeiro (UERJ), Rio de Janeiro, RJ, Brazil

(2) Instituto de Microbiologia, Universidade Federal do Rio de Janeiro (UFRJ), Rio de Janeiro, RJ, Brazil.

(3) Serviço de Endoscopia, Hospital Pedro II, Rio de Janeiro, RJ, Brazil.

Correspondence to: Dr Patrícia Brasil, Disciplina de Parasitologia - FCM - UERJ. Av. 28 de Setembro, 87-fundos, $5^{\circ}$ Andar, Vila Isabel, 20551 -001 Rio de Janeiro, RJ, Brazil. 
BRASIL, P.; PAIVA, D.D. de; LIMA, D.B. de; SILVA, E.J. da; PERALTA, J.M.; SILVA, A.J. da; SODRÉ, F.C.; VILLELA, E.V. \& MOURA, H. - A 3-year follow-up of a Brazilian AIDS patient with protracted diarrhea caused by Enterocytozoon bieneusi. Rev. Inst. Med. trop. S. Paulo, 40 (4): $215-218,1998$.

TABLE 1

Clinical and biological features and detection of microsporidia in an AIDS patient with chronic diarrhea, during a 3 year follow-up a

\begin{tabular}{llllllll} 
Months & 0 & 6 & 12 & 18 & 24 & 30 & 36 \\
\hline Chronic diarrhea & $\mathrm{Y}$ & $\mathrm{Y}$ & $\mathrm{Y}$ & $\mathrm{Y}$ & $\mathrm{N}$ & $\mathrm{N}$ & $\mathrm{Y}$ \\
Weight & 60 & 63 & 60 & 55 & 54 & 72 & 67 \\
CD4 & 22 & 23 & $\mathrm{nd}$ & 10 & 7 & 15 & $\mathrm{nd}$ \\
Alkaline phosphatase* & $\mathrm{nd}$ & 243 & 153 & 150 & $\mathrm{nd}$ & $\mathrm{nd}$ & $\mathrm{nd}$ \\
Drugs & DDI & AZT & AZT & AZT + & AZT + & AZT + & AZT+ \\
& & & & $3 \mathrm{TC}$ & $3 \mathrm{TC}+$ & $3 \mathrm{TC}+$ & $3 \mathrm{TC}+$ \\
& & & & & Indinavir & Indinavir & Indinavir \\
Spores & $(+)$ & $(+)$ & $(+)$ & $(+)$ & $(+)$ & $(-)$ & $(-)$ \\
\hline
\end{tabular}

Abbreviations: * - normal<250; Y - yes; $\mathrm{N}$ - no; (+) present; (-) absent; nd: not done; AZT: zidovudine; DDI: didanosine; 3TC: lamivudine.

significant weight loss of $24 \mathrm{~kg}$ over a 6-month period. Previous infections included pulmonary tuberculosis diagnosed in January 1991 which had been treated with antimycobacterial agents.

The patient had advanced HIV disease as assessed by significantly low total lymphocyte and CD4 lymphocyte counts ( 22 cells $/ \mathrm{mm} 3$ ) at the time of evaluation. He was examined regularly every month for the first four months and periodically thereafter (Table 1). In the 6th month his CD4 cells were determined as well as serum alkaline phosphatase levels and abdominal ultrasonography tests performed because of intense abdominal pain. He was also given prophylactics drugs such as sulpha and trimethoprim for Pneumocystis carinii pneumonia and antiretroviral drug (didanosine, $400 \mathrm{mg} / \mathrm{day}$ ), which was soon changed to zidovudine because of the diarrhea. Later on, a combination therapy was started (Table 1). His stools had neither blood nor leucocytes, but incompletely digested food was frequently found. Routine stool cultures for bacteria and viruses and examination for larvae, ova and cysts were negative for 3 consecutive samples. However, microsporidia spores were detected when thin fecal smears were stained with Weber's chromotrope stain ${ }^{23}$ and with the recently described Gram-chromotrope method ${ }^{18}$. Upper and colonic gastrointestinal endoscopy with biopsies were also carried out during the three-year follow-up. Routine histology, TEM and PCR were performed on biopsy specimens.

Examination of the hematoxylin and eosin (H\&E) stained sections revealed moderate villous atrophy, degeneration and sloughing of infected enterocytes. At high power the epithelium showed disorganized enterocytes which contained clusters of microsporidial spores in the supranuclear region of the villous epithelial cells. Macrophages and plasma cells were seen in the villous lamina propria. Colonic mucosa was negative for CMV inclusions. However, microsporidia spores were found in the duodenal and ileal fragments.

Ultrastructural examination of duodenal biopsy specimens confirmed the presence of microsporidia spores with an electron- lucent endospore, a thin electron-dense exospore and a polar filament with 6 overlapping coils which appeared in cross-section as a series of 3 doublets. These features were compatible with $E$. bieneusi (Fig 1), which was confirmed using PCR with specific primers ${ }^{6}$. Treatment with albendazole ( $400 \mathrm{mg}$ twice a day for 4 weeks) was started. However, the patient was seen 5 times during the 3-year follow-up in the outpatient clinic complaining of diarrhea and microsporidia spores were detected in stool smears everytime (Fig 2). Even though the diarrhea never improved completely, the patient noticed a reduction of bowel movements a few days after the first visit to the clinic when albendazole was initiated. During this time a considerable reduction in the number of spores per microscopic field (0-3) was detected. The diarrhea however, reappeared to the same extent as at the begining of the illness few days after the discontinuation of the drug.

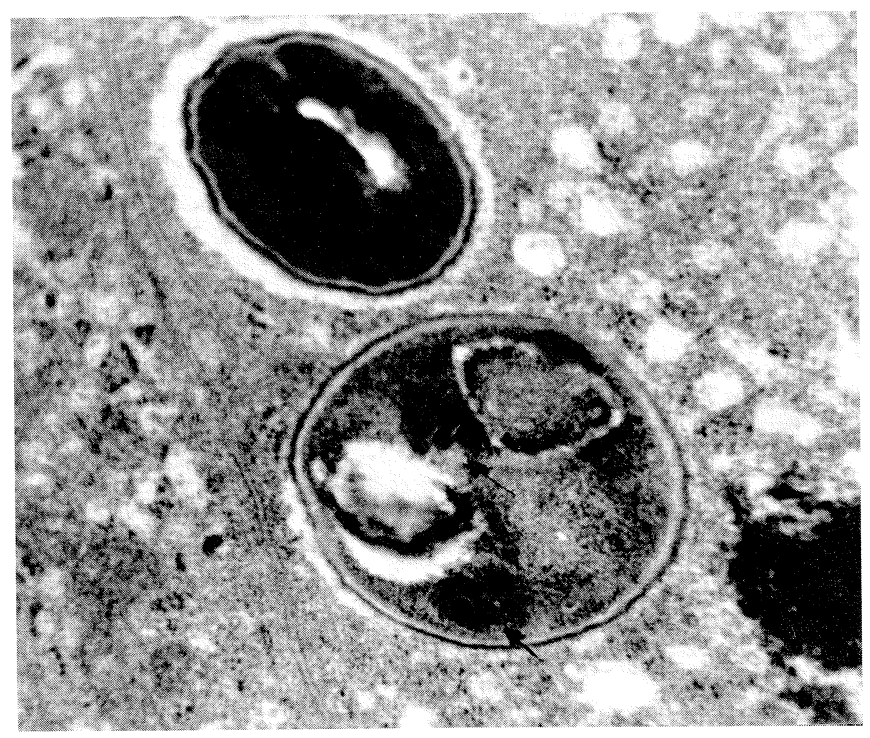

Fig 1. Intracellular Enterocytozoon bieneusi spores with the polar filament containing 6 to 7 overlapping coils in a serie of 3 double features (arrows) (TEM X 45,000) 
BRASIL, P.; PAIVA, D.D. de; LIMA, D.B. de; SILVA, E.J. da; PERALTA, J.M.; SILVA, A.J. da; SODRÉ, F.C.; VILLELA, E.V. \& MOURA, H. - A 3-year follow-up of a Brazilian AIDS patient with protracted diarrhea caused by Enterocytozoon bieneusi. Rev. Inst. Med. trop. S. Paulo, 40 (4): 215-218, 1998.

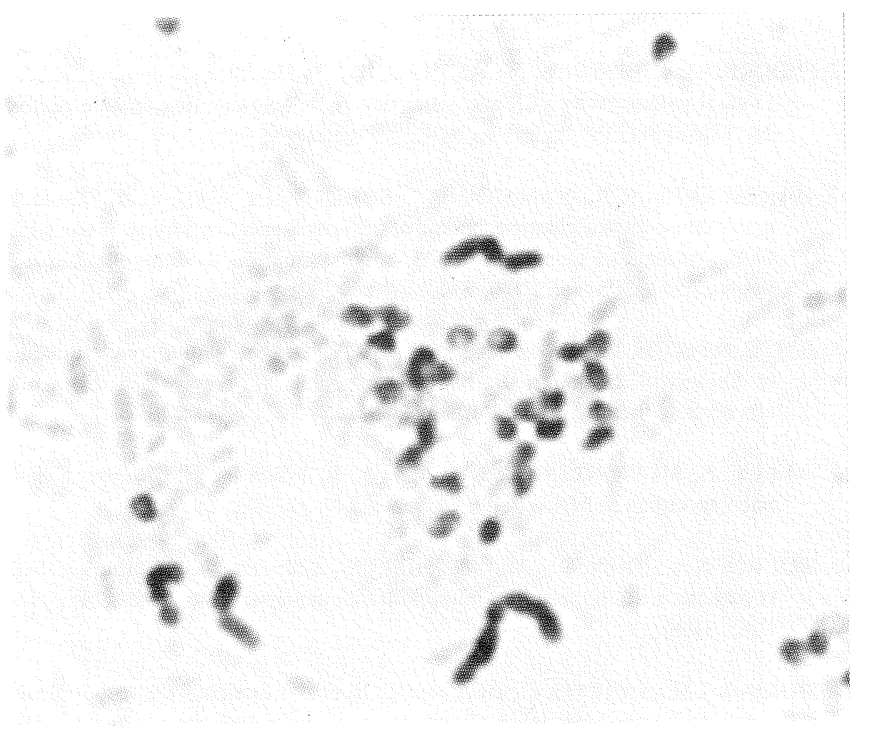

Fig 2. Microsporidial spores in a stool sample (Gram-chromotrope X 1,000)

From August 1994, the patient presented with intermittent diarrhea, with periods of exacerbation. Interestingly, between June 1996 and May 1997, when a combination of nucleoside and protease inhibitors was given for the treatment of the retroviral infection, he experienced a diarrhea-free period without the use of albendazole or other treatment for diarrhea, and at which time he gained about $18 \mathrm{~kg}$. During the follow-up period the patient did not present any clinical manifestation of AIDS besides the diarrhea.

\section{COMMENTS}

We describe a 3-year follow-up of a patient with AIDS and intestinal microsporidiosis due to E. bieneusi. Microsporidial infection was diagnosed after a 6-month period of persistent, unexplained, watery diarrhea. Besides abdominal pain, diarrhea, weight loss, nausea and vomiting the patient had no other symptoms that could be attributed to microsporidiosis ${ }^{25}$. Although our patient had occasional right upper quadrant abdominal pain, evaluation of the alkaline phosphatase levels and abdominal ultrasonography were always unremarkable, which excluded the diagnosis of biliary disease, as E. bieneusi, one of the agents of the so-called AIDS cholangiopathy, was considered as a probable cause ${ }^{25}$.

In our diagnostic evaluation for intestinal microsporidiosis stool examination was sufficient to detect microsporidial spores using either Weber's modified chromotrope technique ${ }^{23}$ or Gramchromotrope $^{18}$ (Fig 2). Tissue obtained by ileo-colonoscopic biopsy yielded equally good results compared with the examination of tissue sections from the upper small intestine, as already described ${ }^{19,24}$. Although there was a higher parasite burden in ileum than in duodenum fragments, the analysis of both confirmed the results of stool examinations, which is a simpler, non-invasive technique for detecting spores of microsporidia. The causative microsporidial species, E. bieneusi, was identified using TEM (Fig. 1) and PCR. During the clinical evolution of the infection, even though we did not have any objective documentation of intestinal function, we observed a clear correlation between the presence of spores of microsporidia in stools and the presence of diarrhea.

The three-year course of diarrhea for this patient and the detection of $E$. bieneusi over a 24 month span demonstrates that microsporidia can cause a protracted diarrhea with a limited wasting syndrome in severely immunodeficient patients, suggesting that the infection by this species of microsporidia itself may not be necessarily life threatening ${ }^{25}$. Attempts to treat the microsporidial infection using albendazole as described recently ${ }^{10}$ seem to be initially successful as the patient presented with less intense, intermittent diarrhea, with no loss of weight, during the 24 initial months of follow-up. Whether the benign natural course of the infection of our patient was supported by the initial specific therapy with albendazole or by the supplemental vitamins and careful nutritional measures, is unknown, since his diarrhea was partially controlled. As a matter of fact, improvement in diagnosis and earlier detection of the microsporidiosis, may have played a role in the alleviation of the symptoms thus improving the quality of his life.

After the 24th month of follow-up, the diarrhea disappeared without any specific treatment and the patient gained about $18 \mathrm{~kg}$. It seems that the combined nucleoside and protease inhibitor therapy contributed to the better resolution of the diarrheal illness, probably as a result of the improvement of immune status, since immune reconstitution has recently been associated with immune-mediated clearance of microsporidia ${ }^{4}$. In human microsporidiosis, the cellular immune response is evidently critical for preventing symptomatic microsporidial disease which is predominantly associated with CD4 cellular deficiency ${ }^{25}$. The lack of evidence of spores of microsporidia in the stools, confirmed by one negative examination of intestinal tissue in the last 8 months illustrates the relationship between parasite burden and diarrheal illness as described recently in a series of patients in Australia ${ }^{4}$.

Improved survival in patients with AIDS occurs as early detection and more efficient treatments for the opportunistic infections and the underlying immunodeficiency are developed ${ }^{16}$, as it seemed to happen to our patient.

\section{RESUMO}

\section{Acompanhamento de 3 anos de um paciente com SIDA e diarréia crônica, protraida, causada pelo Enterocytozoon bieneusi}

Enterocytozoon bieneusi é o mais comum microsporídio agente de infecções gastrointestinais que ocorre predominantemente em pessoas com AIDS. Em todo o mundo os microsporídios são reconhecidos como importantes patógenos oportunistas, entretanto poucos casos já foram diagnosticados no Brasil, provavelmente devido ao pouco conhecimento do quadro clínico que os agentes produzem ou a dificuldades no diagnóstico laboratorial. No presente trabalho relatamos o caso de um paciente brasileiro HIV-positivo acompanhado durante 3 anos, em que foram detectados esporos de microsporídios nas fezes, identificados como Enterocytozoon bieneusi por microscopia eletrô- 
BRASIL, P.; PAIVA, D.D. de; LIMA, D.B. de; SILVA, E.J. da; PERALTA, J.M.; SILVA, A.J. da; SODRÉ, F.C.; VILLELA, E.V. \& MOURA, H. - A 3-year follow-up of a Brazilian AIDS patient with protracted diarrhea caused by Enterocytozoon bieneusi. Rev. Inst. Med. trop. S. Paulo, 40 (4): 215-218, 1998.

nica e PCR. O paciente apresentava diarréia crônica, contagem de linfócitos CD4 abaixo de 100/mm3 e fez uso de albendazol em diferentes ocasiões com melhora transitória da diarréia, que reaparecia logo que a droga era suspensa. Entretanto, o paciente apresentou um grande período sem diarréia e com ganho ponderal de até $18 \mathrm{Kg}$ quando foi prescrito como terapêutica antiretroviral uma combinação de nucleosídios e inibidores de protease.

\section{ACKNOWLEDGMENTS}

We are indebted to Drs. G.S. Visvesvara, David Addis and David A. Schwartz for carefully reviewing the manuscript and for helpful suggestions.

\section{REFERENCES}

1. ANWAR-BRUNI, D.; HOGAN, S.; SCHWARTZ, D. et al. - Atovaquone is effective treatment for the symptoms of gastrointestinal microsporidiosis in HIV-1 infected patients. AIDS, 10: 619-623, 1996.

2. BRASIL, P.; SODRÉ, F.C.; CUZZI-MAYA, T. et al. - Intestinal microsporidiosis in HIV-positive patients with chronic unexplained diarrhea in Rio de Janeiro, Brazil: diagnosis, clinical presentation and follow-up. Rev. Inst. Med. trop. S. Paulo, 38: 97-102, 1996.

3. CALI, A.; KOTLER, D.P. \& ORENSTEIN J.M. - Septata intestinalis N.G., N. Sp., an intestinal Microsporidian associated with chronic diarrhea and dissemination in AIDS patients. J. Euk. Microbiol., 40: 101-112, 1993.

4. CARR, A.; MARRIOTT, D.; FIELD, A. et al. - Treatment of HIV-1 associated microsporidiosis and cryptosporidiosis with combination antiretroviral therapy. Lancet, 351: 256-261, 1998.

5. CURRY, A. \& CANNING, E.U. - Human microsporidiosis. J. Infect., 27: 229$236,1993$.

6. DA SILVA, A.J.; SCHWARTZ, D.A.; VISVESVARA, G.S. et al. - Sensitive PCR diagnosis of infections by Enterocytozoon bieneusi (Microsporidia) using primers based on the region coding for small-subunit rRNA. J. clin. Microbiol., 34: 986-987, 1996.

7. DA SILVA, A.J.; BORNAY-LLINARES, F.J.; DEL AGUILA DE LA PUENTE, C. et al. - Diagnosis of Enterocytozoon bieneusi (Microsporidia) infections by $\mathrm{PCR}$ in stool samples using primers based on the region coding for small-subunit ribosomal RNA. Arch. Path. Lab. Med., 121: 874-879, 1997.

8. DEGIROLAMI, P.C.; EZRATTY C.R.; DESAI, G. et al. - Diagnosis of intestinal microsporidiosis by examination of stool and duodenal aspirate with Weber's modified trichrome and Uvitex 2B stains. J. clin. Microbiol., 33: 805-810, 1995.

9. DESPORTES, I.; LE CHARPENTIER, Y.; GALIAN, A. et al. - Occurrence of a new Microsporidian: Enterocytozoon bieneusi n. g., n. sp., in the enterocytes of a human patient with AIDS. J. Protozool., 32: 250-254, 1985.

10. DIETERICH, D.T.; LEW, E.A.; KOTLER, D.P. et al. - Treatment with albendazole for intestinal disease due to Enterocytozoon bieneusi in patients with AIDS. J. infect. Dis., 169: 178-183, 1994

11. DORE, G.J.; MARRIOT, D.J.; HING, M.C. et al. - Disseminated microsporidiosis due to Septata intestinalis in nine patients infected with the human immunodeficiency virus: response to therapy with albendazole. Clin. infect. Dis., 21: 70-76, 1996.
12. FEDORKO, D.; NELSON, N. \& CARTWRIGHT, C. - Identification of microsporidia in stool specimens by PCR and restriction endonucleases. J. clin. Microbiol., 33: 1739-1741, 1995.

13. HARTSKEERL, R.A.; VAN GOOL, T.; SCHUITEMA, A.R.J. et al. - Genetic and immunological characterization of the microsporidian Septata intestinalis Cali, Kotler and Orenstein, 1993: reclassification to Encephalitozoon intestinalis. J. Parasit., 110: 277-285, 1995.

14. JOSTE, N.; RICH, J.; BUSAM, K.; SCHWARTZ, D. et al. - Autopsy verification of Encephalitozoon intestinalis (microsporidiosis) eradication following albendazole therapy. Arch. Path. Lab. Med., 120: 199-202, 1996.

15. KELlY, P.; MCPHAIL, G. \& NGWENYA, B. - Septata intestinalis: a new microsporidian in Africa (letter). Lancet, 344: 271-272, 1994.

16. MOCROFT, A.; JOHNSON, M.A. \& PHILLIPS, A.N. - Factors affecting survival in patients with the acquired immunodeficiency syndrome. AIDS, 10: 1057 $1065,1996$.

17. MOLINA, J.M.; SARFATI, C.; BEAUVAIS, B. et al. - Intestinal microsporidiosis in human immunodeficiency virus-infected patients with chronic unexplained diarrhea: prevalence and clinical and biologic features. J. infect. Dis., 167: 217-221, 1993.

18. MOURA, H.; NUNES DA SILVA, J.L.; SODRÉ, F.C. et al. - Gram-chromotrope: a new technique that enhances detection of Microsporidial spores in clinical samples. J. Euk. Microbiol., 43: 94S-95S, 1996.

19. OMBROUCK, C.; CICERON, L. \& DESPORTES-LIVAGE, I. - Specific and rapid detection of Microsporidia in stool specimens from AIDS patients by PCR. Parasite, 3: 85-86, 1996.

20. ORENSTEIN, J.M.; TENNER, M.; CALI, A. et al. - A microsporidian previously undescribed in humans, infecting enterocytes and macrophages, and associated with diarrhea in an acquired immunodeficiency syndrome patient. Hum. Path., 23: 722 - 728, 1992.

21. SCHATTENKERK, J.K.M.E.; VAN GOOL, T.; VAN KETEL, R.J. et al. - Clinical significance of small-intestinal microsporidioses in HIV-1-infected individuals. Lancet, 37: 895-898, 1991 .

22. SCHWARTZ, D.A.; WEBER, R. \& VISVESVARA, G.S. - Microsporidiosis in HIV positive patients: current methods for diagnosis using biopsy, cytologic, ultrastructural, immunological, and tissue culture techniques. Folia parasit., 41: 101-109, 1994.

23.WEBER, R.; BRYAN, R.T.; OWEN, R.L. et al. - Improved light-microscopical detection of microsporidia spores in stool and duodenal aspirates. New Engl. J. Med., 326: 161-166, 1992.

24.WEBER, R.; MULLER, A.; SPYCHER, M.A. et al. - Intestinal Enterocytozoon bieneusi microsporidiosis in an HIV-infected patient: diagnosis by ileo-colonoscopic biopsies and long-term follow up. Clin. Invest., 70: 1019-1023, 1992.

25. WEBER, R.; BRYAN, R.T.; SCHWARTZ, D.A. et al. - Human Microsporidial infections. Clin. Microbiol. Rev., 7: 426-461, 1994.

26. WEBER, R.; SAUER, B.; SPYCHER, M.A. et al. - Detection of Septata intestinalis (Microsporidia) in stool specimens, and coprodiagnostic monitoring of sucessful treatment with albendazole. Clin. infect. Dis., 19: 342-345, 1994.

27. WUHIB, T.; SILVA, T.M.J.; NEWMAN, R.D. et al. - Cryptosporidial and microsporidial infections in human immunodeficiency virus-infected patients in northeastern Brazil. J. infect. Dis., 170: 494-497, 1994.

Received: 02 March 1998

Accepted: 09 June 1998 